\title{
VALIDATION OF THE MALAY-TRANSLATED EXPECTANCY VALUE MODEL QUESTIONNAIRE AND MULTI-DIMENSIONAL SPORTSPERSONSHIP ORIENTATIONS SCALE AMONG MALAYSIAN ADOLESCENCE FIELD HOCKEY PLAYERS
}

\author{
Kanagarajah Rarujanai ${ }^{1 *}$, Teo Eng Wah ${ }^{1 *}$, Arthur Ling1, Chin Ngien Siong ${ }^{2}$, Mansur ${ }^{3}$ \\ ${ }^{1}$ University of Malaya, Malaysia \\ ${ }^{2}$ Institut Pendidikan Guru Kampus Batu Lintang, Malaysia \\ ${ }^{3}$ Yogyakarta State University, Indonesia \\ *e-mail: vteo2@um.edu.my
}

\begin{abstract}
This study presents an overview of Malaysian adolescent field hockey players' expectancy beliefs, subjective values and sportspersonship attitude. We aimed to translate and validate two questionnaires i.e., Expectancy Value Model Questionnaire (EVMQ) and Multi-dimensional Sportspersonship Orientations Scale (MSOS) to Malay language. The EVMQ and MSOS were translated into the Malay language using the back translation method. A total of 230 respondents (15.40 \pm 2.17 years $)$ were recruited for this study. The result of analyses are EVMQ-M $(M=5.38 \pm .95)$ and MSOS-M $(M=3.64 \pm .40)$ respectively. Content validity was checked by experts in the fields for content conformity and culture bias whereas face validity was confirmed by ten participants. Both questionnaires showed high internal consistency (reliability); EVMQ-M $(\alpha=.94)$ and MSOS-M $(\alpha=$ $.82)$. Data fits were checked using the Structural Equation Model; EVMQ-M $\left(\chi^{2}(d f=39)=84.07, \mathrm{CFI}\right.$ $=.97, \mathrm{GFI}=.94, \mathrm{TLI}=.95, \mathrm{RMSEA}=.07, \mathrm{ChiSq} / \mathrm{df}=2.16)$ and MSOS-M $\left(\chi^{2}(d f=146)=321.76\right.$, $\mathrm{CFI}=.92, \mathrm{GFI}=.87, \mathrm{TLI}=.90, \mathrm{RMSEA}=.07, \mathrm{ChiSq} / \mathrm{df}=2.20)$ also showed good construct validity. The translated Malay version EVMQ-M and the MSOS-M are reliable and valid instruments to assess Malaysian adolescent field hockey players.
\end{abstract}

Keywords: expectancy belief, subjective values, sportspersonship attitude, adolescent, field hockey

\section{VALIDASI KUESIONER EXPECTANCY VALUE MODEL DAN MULTI-DIMENSIONAL SPORTSPERSONSHIP ORIENTATIONS SCALE BAGI PEMAIN REMAJA HOKI DI MALAYSIA}

\begin{abstract}
Abstrak: Penelitian ini menyajikan gambaran umum tentang kepercayaan harapan, nilai-nilai subjektif dan sikap sportif pemain remaja hoki Malaysia. Penelitian ini bertujuan untuk menerjemahkan dan memvalidasi dua kuesioner yaitu Expectancy Value Model Questionnaire(EVMQ) dan Multi-dimensional Sportspersonship Orientations Scale (MSOS) ke Bahasa Melayu. EVMQ dan MSOS diterjemahkan dalam Bahasa Melayu menggunakan metod terjemahan kembali. Sebanyak 230 responden $(M=15,40$ $\pm 2,17$ tahun) direkrut untuk penelitian ini. Hasil analisis menunjukkan bahawa EVMQ-M $(M=5,38$ $\pm 0,95)$ dan MSOS-M $(M=3,64 \pm 0,40)$ masing-masing. Validitas isi dilakukan oleh penterjemah anggota tim pakar untuk kesesuaian ISI dan bias budaya sementara validitas muka dikonfirmasi oleh sepuluh peserta. Kedua kuesioner menunjukkan konsistensi internal/ realibilitas yang tinggi; EVMQ-M $(\alpha=0,94)$ dan MSOS-M $(\alpha=0,82)$. Validitas 'data fits' diperiksa menggunakan Structural Equation Modeling; EVMQ-M $\left(\chi^{2}(d f=39)=84,07, \mathrm{CFI}=0,97\right.$, GFI $=0,94$, TLI $=0,95$, RMSEA $=0,07$, $\mathrm{ChiSq} / \mathrm{df}=2,16)$ dan MSOS-M $\left(\chi^{2}(d f=146)=321,76, \mathrm{CFI}=0,92, \mathrm{GFI}=0,87, \mathrm{TLI}=0,90, \mathrm{RMSEA}=\right.$ $0,07, C h i S q / d f=2,20)$ juga menunjukkan validitas konstruk yang baik. EVMQ-M dan MSOS-M versi Melayu yang telah diterjemahkan adalah instrumen yang andal dan valid untuk menilai pemain remaja hoki padang Malaysia.
\end{abstract}

Kata Kunci: kepercayaan harapan, nilai-nilai subjektif, sikap sportif, remaja, hoki padang 


\section{INTRODUCTION}

Field hockey is an outdoor game played widely across the world (Saeed, Abd Rahim, $\&$ Abida, 2015). It was proposed that there are four main game aspects in field hockey namely psychological, technical, physiological and tactical that affect field hockey players at top level competition (Saeed et al., 2015).

Psychologists argues that psychological elements like motivation, concentration, mental strength, confidence, team understanding and anxiety control determine how well a field hockey player can perform at various levels of competitions (Chin, Khoo, \& Low, 2009). Hence, good mastery of these psychological elements are perquisite for a successful sport career. Besides a positive sports environment, good psychological elements may assist players in making decisive role in an important match (Ghildiyal, 2015).

Expectancy-related beliefs, subjective task values and sportspersonship attitude are among the psychological components that strongly affect adolescents sport performance (Chin et al., 2009). The quality found among the adolescent athletes today will likely influence the quality of the nation's future sport performance. Understanding the relationships between these three components are critical and can be used to improve the adolescents' performance in field hockey. These three psychological components can be explained based on two theoretical models i.e., Expectancy Value Model and Achievement Goal Theory.

\section{Expectancy Value Model}

The expectancy-value model of achievement-related choices (Eccles, Adler, Futterman, Goff, Kaczala, Meece, \& Midgley, 1983) had been widely applied in educational and psychological studies (Conley, 2012; Plante, O'Keefe \& Théorêt, 2013). This model explains that motivation has two different function; expectancy related beliefs and subjective task values (Wigfield \& Cambria, 2010).

Expectancies for success and belief about individual's ability are two main components of expectancy related beliefs. Expectancy for success explains how an individual will evaluate how well he/she can engage and complete the task as an individual. Whereas, ability-related belief deals with on how individual deals with their evaluation of self-ability and competence (Wigfield \& Cambria, 2010).

While, subjective task value consists of four components i.e., utility value, attainment value, intrinsic value and cost value. Attainment value focuses on the beliefs regarding expected performance on a task by exhibiting self-image and core personnel value (Conley, 2012). Intrinsic value explains the pleasure one gets from performing any task that results in positive attitude to produces important psychological consequences for them.

Utility value or usefulness discusses on how an individual can relate his current task to his future plans or goals. In many aspects utility value is similar to extrinsic motivation (Wigfield $\&$ Cambria, 2010). Cost value emphases on the demand of a given task. Cost deals with negative features of performing a task which including loss of time and energy for other choices (Plante et al., 2013).

\section{Achievement Goal Theory}

Achievement goal theorists had widely used achievement goal orientations to investigate behavioural motivation (Duda, Olson \& Templin, 1991). This theory highlights different reasons that someone engage in an achievement-related behaviours or settings (Nicholls, 1989). This theory highlights two main goal orientations; task orientations and ego orientations. In sport, when an athlete is basically motivated by personal mastery, self-improvement and self-initiated achievement, he is said to be a task-orientated person. Athletes presume their performance leading to success or failure using self-reflection views in a very subjective manner.

Ego orientation goals is present when athlete compare themselves or their performance with other athletes. Any victory or defeat resulted from their performance will be subjected to social comparison (Chin et al., 2009). An egoorientated athlete is motivated by collective effort in order to win and demonstrate the best performance to show off (Nicholls, 1989).

Task orientation explains athletes are more respectful to their social surroundings as well as competition rules and official (Duda et al., 1991). They prefer good mutual understanding by obeying to the moral and ethics when facing any conflicts, while this does not apply to ego orientated athletes (Duda \& Nicholls, 
1992). An ego orientated athlete is considered more aggressive and more likely to engage in unsportsperson-ship like conducts (Duda et al., 1991; Duda \& Nicholls, 1992). Monacis, Estrada, Siantra, Tanucci, \& Palo (2013) found out that task orientated athlete are more respectful with greater sportsmanship attitude while ego orientated athlete would predict antisocial behaviours.

\section{Sportspersonship Attitude}

Sportspersonship is a key element in developing characters through sports or other related activities (Ghildiyal, 2015). A certain and precise definition of sportspersonship is not viable as most people have different opinions about what sportspersonship is. Barkoukis \& Mouratidou (2015) stated that "sportspersonship represents a multifaceted construct". In sporting culture, sportspersonship is the behaviour exhibited by an individual while participating in the sport. This character developing element in sport, indirectly develop individual's moral judgement and fair play regarding the competition rules either intentionally or deliberately (Ghildiyal, 2015).

\section{Previous empirical literature}

In previous study, Conley (2012) investigated the relationship between the expectancy beliefs, task values and achievement goals. Conley's (2012) evaluated 1870 Vietnamese and Latino students, they found that by integrating achievement goal and expectancy value paradigm, the prediction of affect and achievement can be improved gradually.

In another related study, Plante et al. (2013) assessed the empirical validity of four contrasting theoretical conceptions involving achievement goals and expectancy values to investigate two dominant subjects i.e., mathematics and language arts among 697 French-speaking grade six and grade eight students in Canada. Their findings suggested that expectancy-value variables predict achievement-related outcomes both directly and indirectly through achievement goals.

Based on the extensive literature search, to date there is no study on Malaysian adolescent field hockey players' belief, value and sportspersonship attitude had been conducted on field hockey in Malaysia. Although there are various validated questionnaires in English to measure expectancy beliefs, subjective values and sportspersonship but to date there is no validated Malay version of EVMQ and MSOS questionnaires.

This study is urgent because properly translated and validated Malay EVMQ and MSOS questionnaires will help respondents who are less proficient in English to understand the survey questions better, hence provide more accurate and better quality answers. Accurate information will also help coaches and physical education teachers understand players better and more mindful in boasting hockey players' motivation as participation in this sport has seen some decline in recent years. Thirdly, to a certain extend the current translated and validated into Malay language questionnaires, can be used in other Malay speaking countries. In summary, the aim of this study was to translate and validate the EVMQ and MSOS to the Malay language.

\section{METHODS}

\section{Ethics statement}

This study obtained the approval from University Malaya Research Ethics Committee (UMREC) Reference Number: UM.TNC2/ UMREC - 212). The participants below the age of 18 years provided written parental consent while the participants above 18 years old signed the Consent Form.

\section{Participants}

The participants of this study were 230 adolescent field hockey players from Malaysia. They were between 12 to 19 years old ( $M=$ $15.40 \pm 2.17$ year) who play actively at club, school or state level.

\section{Measures}

Demographic characteristics. The first part of our survey consists of demographic questions such as gender, age, date of birth, race, school or institution address and level of sport participation were collected.

Beliefs and values. Expectancy Value Model Questionnaire (EVMQ; Eccles et al., 1983) consists of 11 items rated on 5-point Likert scale. Item 1 to 5 measure the expectancyrelated beliefs while item 6 to 11 measure the subjective task values.

Sportspersonship attitude. The 
Multidimensional Sportspersonship Orientation Scale (MSOS; Vallerand, Brière, Blanchard \& Provencher, 1997) consists of 25 items rated on a 5-point Likert scale. MSOS has five subscales i.e., respect for social conventions of sport, respect for rules and officials, respect and concern for the opponent, respect for one's commitment toward participation in sport, and negative approach toward the practice of sport.

\section{Procedure}

\section{Translation of the EVMQ and MSOS from English to Malay}

The Brislin's back translation procedure was carried out because many researchers considered this procedure as the choice method in translating cross cultural research instruments (Brislin, 1970; Teo, Lee, Khoo, \& Morris, 2015).

Firstly, the questionnaires were translated independently from English language (source language) into Malay language (target language) by three professional translators. The researcher team then gathered all three translated versions, reviewed, compared and edited by research team to produce a draft Malay version questionnaire. Then, the second group of bilingual translators consists of two professional translators back translated the agreed upon draft Malay version back to English independently without referring to the original version (Teo et al., 2015).

The research team consisting of two sports psychologists, state hockey coaches, an officer from local sports council and a culture and language specialist reviewed and evaluated the back translated English versions based on the original English version of EVMQ and MSOS questionnaires. The research team assessed the clarity, language difficulties, item discrepancies and possible cultural insensitivity before rectify them. The process of forward and back translation of items was repeated for three times until the research team agreed upon the final version. The final Malay versions were subsequently tested for face validity. After the confirmation, the Malay version of both the questionnaires was distributed to the participants to collect evidence of reliability and validity evidence (Brislin, 1970; Teo et al., 2015).

\section{Data analyses}

Preliminary descriptive data analyses were conducted to examine for data normality.
Later, confirmatory factor analyses (CFA) were conducted to establish baseline measurement model of EVMQ and MSOS respectively. SPSS version 23 and AMOS version 23 software were used for above data analysis purpose.

\section{FINDINGS AND DISCUSSION Findings}

After performing preliminary study, translating and validating Expectancy Value Model Questionnaire (EVMQ) and Multidimensional Sportspersonship Orientations Scale (MSOS) to facilitate the evaluation of the level of expectancy value, subjective values and sportspersonship attitude amongst generally in Malaysia, results and discussion are presented as follows. The reliability and validity evidence / results of the EVMQ-M are presented first then followed by the results of MSOS-M.

\section{Descriptive analysis}

A total of two hundred and thirty field hockey adolescent field hockey players from various districts of Sarawak answered the questionnaires and relevant demographics information were collected (Table 1). As it may be seen in Table 1, 117 respondents $(50.9 \%)$ were men and 113 (49.1\%) were women. From these, $111(48.3 \%)$ were 16 to 19 years, 119 $(51.7 \%)$ were 12 to 15 years. $74(32.2 \%)$ of the participants came from northern Sarawak, 73 (31.7\%) from central Sarawak and 83 (36.1\%) from southern of Sarawak.

Table 1. Distribution of Respondents in Terms of Status of Gender, Age Group and Location

\begin{tabular}{llcc}
\hline \multirow{2}{*}{ Status } & & \multicolumn{2}{c}{ Frequency } \\
\cline { 3 - 4 } & & $\boldsymbol{n}$ & $\mathbf{\%}$ \\
\hline \multirow{3}{*}{ Gender } & Male & 117 & 50.9 \\
& Female & 113 & 49.1 \\
& Total & 230 & 100.0 \\
\hline Age group & $12-15$ & 119 & 51.7 \\
& $16-19$ & 111 & 48.3 \\
& Total & 230 & 100.0 \\
\hline \multirow{3}{*}{ Location } & Northern & 74 & 32.2 \\
& Central & 73 & 31.7 \\
& Southern & 83 & 36.1 \\
& Total & 230 & 100.0 \\
\hline
\end{tabular}

Note. $n=$ number of participants. 


\section{Expectancy Value Model Questionnaire (EVMQ-M) \\ Descriptive Statistic}

Table 2 shows the mean and standards deviation of subscales measuring the expectancy and beliefs and values using EVMQ-M. The Expectancy belief and Attainment subscales both recorded highest mean score $(M=5.42)$ with the standard deviation of .98 and 1.55 respectively. This was followed by subscale Utility $(M=5.34$; $S D=1.22)$ and Intrinsic $(M=5.28 ; S D=1.12)$.

Table 2. Descriptive Statistic Results of

\begin{tabular}{lcc}
\multicolumn{2}{c}{ EVMQ-M $(\boldsymbol{n}=\mathbf{2 3 0})$} \\
\hline & Mean $(\boldsymbol{M})$ & $\begin{array}{c}\text { Standard } \\
\text { Deviation }(\boldsymbol{S D})\end{array}$ \\
\hline EVMQ-M & & \\
Overall & 5.38 & .95 \\
Expectancy belief & 5.42 & .98 \\
Attainment & 5.42 & 1.55 \\
Intrinsic & 5.28 & 1.12 \\
Utility & 5.34 & 1.22 \\
\hline
\end{tabular}

\section{Reliability evidence}

Reliability of the translated questionnaires was measured by means of alpha coefficients to assess the internal consistency (Cronbach's alpha). Nunnally (1978) offered a rule of thumb of .7 or equal alpha value as good internal consistency. The EVMQ-M had good internal consistency determined by Cronbach's alpha. Table 3 shows the reliability test results for each subscale in EVMQ-M.

Table 3. Reliability Test Results of EVMQ-M

\begin{tabular}{lcc}
\hline & $\begin{array}{c}\text { Number of } \\
\text { Items }\end{array}$ & Cronbach's $\boldsymbol{\alpha}$ \\
\hline EVMQ-M & & \\
Overall & 11 & .90 \\
Expectancy belief & 5 & .87 \\
Attainment & 2 & .85 \\
Intrinsic & 2 & .71 \\
Utility & 2 & .69 \\
\hline
\end{tabular}

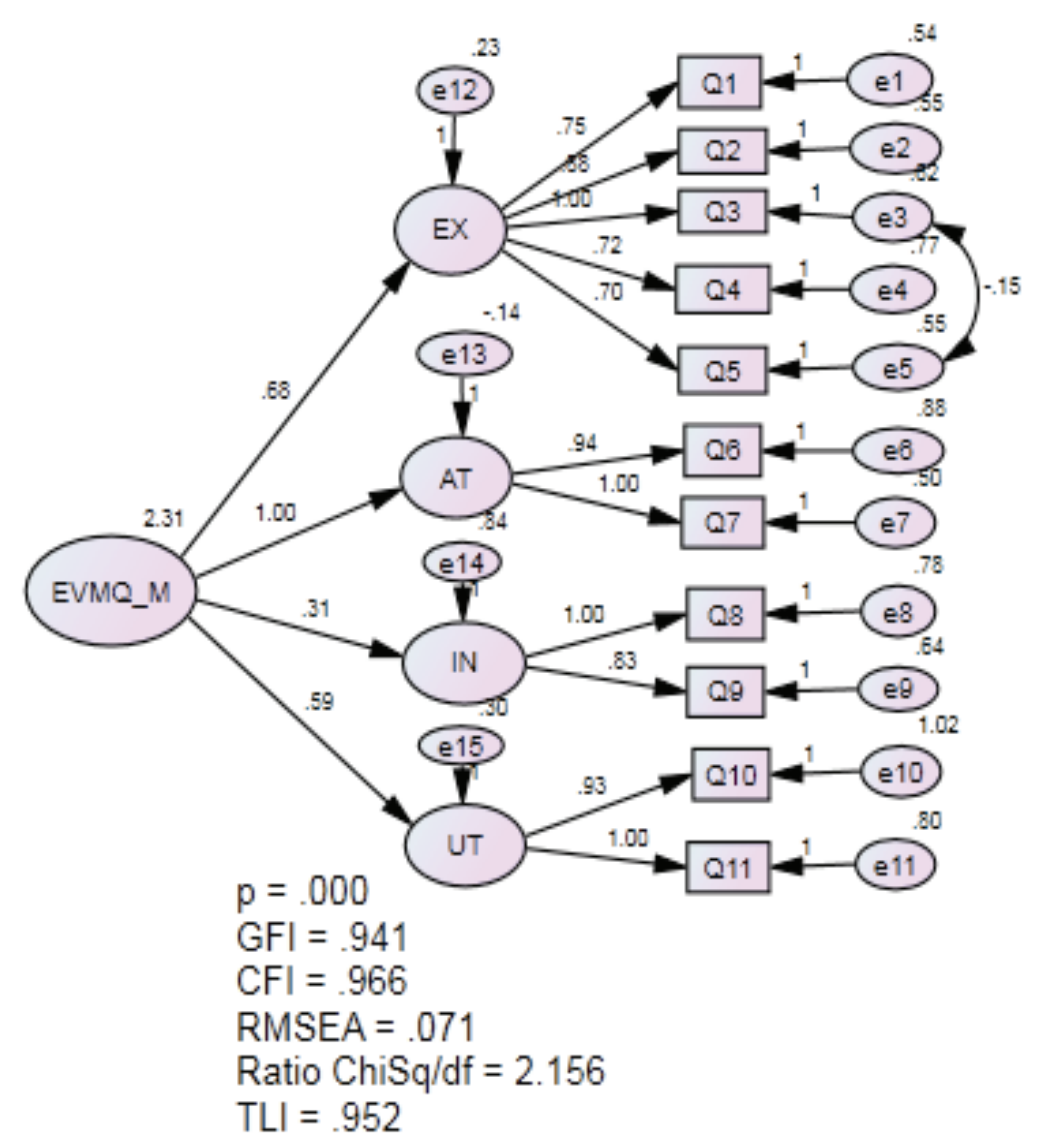

Figure 1. Final CFA Model of the EVMQ-M Measurement 


\section{Validity evidence}

For validity evidence, content, construct and face validities were conducted. Two hundred thirty adolescent field hockey players were given the final version of Malay-translated questionnaires. Throughout the iteration and validation process, there was no evidence of cultural issues or language difficulties. All the items reflected sufficient cultural objectivity, comprehensibility and achieved conceptual equivalence.

In order to measure for construct validity, the model fit of the questionnaires to the observed data was tested by means of Confirmatory Factor Analysis (CFA). Second order CFA statistical analysis method was performed as these questionnaires comprise of numerous underlying sub-constructs and each sub-construct is measured using several items (Mustapha \& Bolaji, 2015). A high item loading indicates that there is much in common between the factor and the respective item (Sharma, 1996). Loadings below .32 are considered as poor, $\geq .45-.54$ as fair, $\geq .55-.62$ as good, $\geq .63$ -.7 as very good, and .7 and above as excellent (Sharma, 1996).

Beside factor loadings, Hair, Black, Babin, \& Anderson (2010) recommended at least four fit indexes to evaluate construct validity of a measurement model. Table 4 shows the important fit indexes suggested by Hair et al. (2010).

The Expectancy Value Model Questionnaire subscales are represented by 5 items under expectancy belief and 2 items each under the other three subscales respectively. Based on Structural Equation Modelling (SEM), no items deletion was performed on EVMQ-M as all factor loadings are above .55. The factor loading $(\lambda)$ for the EVMQ-M after 3 iterations of modification indices performed ranges from .68 to .90 . The current study examined the main five fit indexes suggested by Hair et al. (2010) to estimate construct validity of the measurement model used. Construct validity based on model fit indices showed good model fit. EVMQ-M revealed data fit of $\chi^{2}(d f=39)=84.07$, CFI $=$ $.97, \mathrm{GFI}=.94, \mathrm{TLI}=.95, \mathrm{RMSEA}=.07, \mathrm{ChiSq} /$ $d f=2.16$ (Figure 1).

\section{Face Validity EVMQ-M}

In order to examine for face validity, the Malay-translated versions of questionnaires were distributed to ten randomly selected participants to test for face validity. The participants were asked to respond whether the items reflect what it was supposed to test or evaluate. They were also requested to include any relevant comments.

The ten participants recruited for face validity responded that the items of EVMQ-M reflect all four subscales (expectancy, attainment, intrinsic and utility). Hence, EVMQ-M reflect what it was supposed to test.

\section{The Multidimensional Sportspersonship Orientation Scale (MSOS) \\ Descriptive Statistic}

Table 5 shows the mean and standards deviation of subscales measuring the expectancy and beliefs and values using MSOS-M. Respect for one's commitment toward participation in sport recorded highest mean score $(M=4.12 ; S D$ $=.66)$. This was followed by subscale respect for rules and officials $(M=4.05 ; S D=.69)$, respect for social conventions of sport $(M=4.04 ; S D=$ .73), respect and concern for the opponent ( $M=$ 3.98; $S D=.73$ ) and negative approach toward the practice of sport $(M=2.17 ; S D=.73)$.

Table 4. Fit Indexes for Measurement Model (Construct Validity)

\begin{tabular}{lcc}
\multicolumn{1}{c}{ Name of Category } & Index & Criteria \\
\hline Root Mean Square of Error & RMSEA & RMSEA $<.08$ \\
Approximation & & Acceptable $\leq .10$ \\
Goodness of Fit Index & GFI & GFI $>.90$ \\
Comparative Fit Index & CFI & CFI $>.90$ \\
ChiSquare/degree of freedom & Chisq/df & Chisq $/ d f<5.0$ \\
Tucker-Lewis Index & TLI & TLI $>.90$ \\
\hline
\end{tabular}


Table 5. Descriptive Statistic Results of MSOS-M $(n=230)$

\begin{tabular}{lcc}
\hline & Mean $(\boldsymbol{M})$ & $\boldsymbol{S D}$ \\
\hline MSOS-M & & .40 \\
Overall & 3.64 & .73 \\
Respect for social conventions of sport & 4.04 & .69 \\
Respect for rules and officials & 4.05 & .66 \\
Respect for one's commitment toward participation & 4.12 & \\
in sport & & .73 \\
Respect and concern for the opponent & 3.98 & .73 \\
Negative approach toward the practice of sport & 2.17 & \\
\hline
\end{tabular}

Table 6. Reliability of MSOS-M

\begin{tabular}{lcc}
\hline & Number of Items & Cronbach's $\boldsymbol{\alpha}$ \\
\hline MSOS-M & & \\
Overall & 25 & .80 \\
Respect for social conventions of sport & 5 & .82 \\
Respect for rules and officials & 5 & .78 \\
Respect for one's commitment toward participation in sport & 5 & .78 \\
Respect and concern for the opponent & 5 & .80 \\
Negative approach toward the practice of sport & 5 & .71 \\
\hline
\end{tabular}

\section{Reliability evidence}

Reliability of MSOS-M was measured with exactly the same method EVMQ-M with .7 or equal alpha value as good internal consistency. The EVMQ-M had good internal consistency determined by Cronbach's alpha. Table 6 shows the reliability test results for each subscale in MSOS-M. The reliability results of this questionnaire demonstrated good and acceptable internal consistency.

\section{Validity evidence}

Similar to EVMQ-M, content, construct and face validities of MSOS-M were conducted showing no evidence of cultural issues or language difficulties at the end of the iteration and validation process. All the items reflected sufficient cultural objectivity, comprehensibility and achieved conceptual equivalence.

In order to measure for construct validity, the model fit of the questionnaires to the observed data was tested by means of Confirmatory Factor Analysis (CFA). Sharma's (1996) factor loading guidelines and Hair et al. (2010) fit indexes suggestions were used for the validity process.

Based on Structural Equation Modelling (SEM), six items (Item 1, Item 3, Item 12, Item 22, Item 24 and Item 25) from MSOS-M were deleted due to factor loadings that are lower than .55. Hence, the total items for MSOS-M were reduced from the original 25 items (MSOS) to 19 items (MSOS-M). Based on the CFA and SEM analysis, various other validity evidence were also obtained as shown below. This leaves the 'respect for rules and officials' subscale with 3 items while all the other four subscales represented by 4 items after the item deletion. This number of items under one subscale is considered sufficient for internal consistency analysis (Hair et al., 2010).

After the items deletion due to factor loadings that are lower than .55 and modification indices for 3 iterations performed, the factor loading for the MSOS-M ranging between .59 and .79. The factor loadings of both questionnaires conformed to the recommendation of $\geq .55$. Sharma (1996) reported that factor loadings should be greater than .55 should be good.

Construct validity based on model fit indices showed good model fit. MSOS-M revealed data fit of $\chi^{2}(d f=146)=321.76, \mathrm{CFI}=$ $.92, \mathrm{GFI}=.87, \mathrm{TLI}=.90, \mathrm{RMSEA}=.07, \mathrm{ChiSq} /$ $d f=2.20$ (Figure 2). Our GFI value is close to .9 , which shows a relatively good fit (Bentler, 1990). All the fit indices met the requirements for SEM analysis (Hair et al., 2010). Therefore, both questionnaires demonstrated good data fit. 


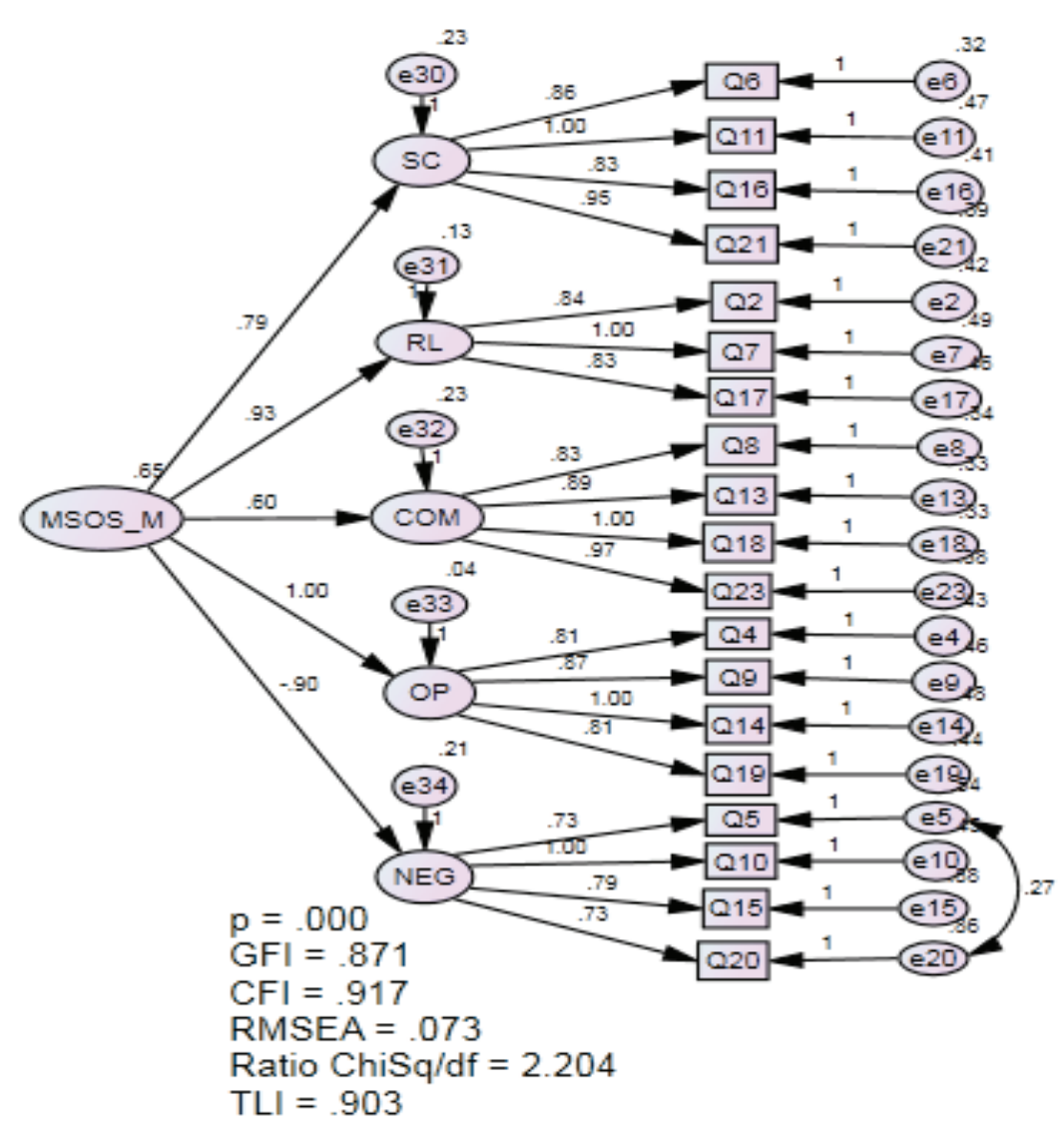

Figure 2. Final CFA Model of the MSOS-M Measurement

\section{Face Validity}

All the face validity respondents commented that MSOS-M correctly represent five subscales on respect for social conventions of sport, respect for rules and officials, respect for one's commitment toward participation in sport, respect and concern for the opponent and negative approach. Hence, MSOS-M reflect what it was supposed to evaluate.

\section{Discussion}

The aim of this study was to translate and validate the Expectancy Value Model Questionnaire and Multi-dimensional Sportspersonship Orientations Scale to the Malay language. In the Expectancy Value Model Questionnaire, all the 11 items were maintained without any reduction to the subscales as well. All four subscales; expectancy beliefs (5 items), attainment (2 items), intrinsic (2 items) and utility ( 2 items) were maintained as mentioned in the original questionnaire by Zhu, Sun, Chen, \& Ennis (2012). According to Worthington \& Whittaker (2006), it is possible to retain a subscale with only two items if the items are highly correlated (i.e., $r>.70$ ) and relatively uncorrelated with other variables.

Expectancy belief and task values have a statistically significant linear relationship as we can see that the Cronbach's alpha coefficient for all four subscales (expectancy belief, attainment, intrinsic and utility) is .89; alpha range from .70 to .87 . Consistent with many studies conducted within the expectancy-value framework (Zhu et al., 2012; Roure \& Lentillon-Kaestner, 2018; Østerlie, Løhre, \& Haugan, 2018), the results of this study revealed good correlations between all the four subscales involved in EVMQ-M.

The EVMQ-M was found to be reliable with good internal consistency with alpha value parallel to studies that have used the translated native language Expectancy Value Model 
Questionnaire. According to Zhu et al. (2012), the English version of EVMQ has sufficient construct validity and internal reliability. In their study within the elementary and middle school physical education and sports contexts, Zhu et al. (2012) recorded the Cronbach's alpha values ranged from .66 to .89 for expectancy belief and task value constructs. Their study which was based on 1,714 students from 26 various elementary and middle schools, showed a good fit (validity) with values of $\chi^{2}=213.73, d f=85$, $\mathrm{SRMR}=.043, \mathrm{CFI}=.97, \mathrm{RMSEA}=.042[90 \%$ $\mathrm{CI}=.035 ; .049])$.

A translation and validation study conducted by Østerlie et al. (2018) translated English version of Expectancy Value Model Questionnaire into Norwegian version among 338 adolescents in PE classes. It was reported that the Cronbach alpha values ranged from .72 to .92 for expectancy belief and task value constructs (Østerlie et al., 2018). In another similar study that translated English version of Expectancy Value Model Questionnaire into French, Roure \& Lentillon-Kaestner (2018) recorded Cronbach's alpha values for the four subscales as $.91, .79, .71$ and .77 respectively, indicating that all four subscales attained acceptable internal reliability (Hair et al., 2010; Nunnally, 1978). On the whole, the current findings were that EVMQ-M recorded adequate internal reliability and construct validity for measuring adolescence field hockey players in Malaysia using Malay language.

Construct validity results from second order CFA showed good model fit. EVMQ-M revealed fit data of $\chi^{2}(d f=39)=84.07$, CFI $=.97, \mathrm{GFI}=.94, \mathrm{TLI}=.95, \mathrm{RMSEA}=.07$, $C h i S q / d f=2.16$. The calculated values for the important indicators like GFI, CFI and RMSEA were reported within the standard region (Hair et al., 2010). Our results are almost similar with study conducted by Roure \& Lentillon-Kaestner (2018) that claimed similar model fit with CFI $=.96, \mathrm{TLI}=.95$ and RMSEA $=.06$. Østerlie et al. (2018) reported the model fit indicators CFI $=.97$, TLI $=.96$ and RMSEA $=.08$, showing almost similar results with the current study. Similarly, Østerlie et al. (2018) revealed a good fit for their study with values of $\chi^{2}=103.85, d f=$ $38, \mathrm{SRMR}=.048, \mathrm{CFI}=.97$ and RMSEA $=.08$ with $p$-value $<.05$.
Whereas, in the second questionnaire, the items in the Multi-dimensional Sportspersonship Orientations Scale with originally 5-subscales were reduced from 25 items to 19 items maintaining sufficient representation of the original variables. This was after six items (Item 1, Item 3, Item 12, Item 22, Item 24 and Item 25) were deleted due to factor loadings that are lower than .55 that were considered poor or fair (Sharma, 1996). The number of items under each subscales shows some changes compared to the original version of the questionnaire which recorded five items under each subscales (Vallerand et al., 1997). After the item deletion MSOS-M recorded 4 items for the subscale 'respect for social conventions of sport', 3 items for the subscale 'respect for rules and officials', 4 items for the subscale 'respect for one's commitment toward participation in sport', 4 items for the subscale 'respect and concern for the opponent' and 4 items for the subscale 'negative approach toward the practice of sport'.

The overall Cronbach's alpha value for all five subscales in MSOS-M is .84, while individual subscale alphas ranges from .71 to .82. The 'negative approach toward the practice of sport' subscale recorded the lowest value of Cronbach's alpha which is consistent with many other similar studies conducted using 5-subscales Multi-dimensional Sportspersonship Orientations Scale (Monacis et al., 2013; Perry, 2014).

Manouchehri, Tojari, \& Hejabi (2015) conducted a study to determine the validity and reliability of MSOS involving 373 young athletes from Pakdasht, Iran found that Cronbach's alpha ranges from .72 to .86 . The data fits for MSOS are $\chi^{2} / d f=2.03, \mathrm{NFI}=.94, \mathrm{GFI}=.90, \mathrm{AGFI}=.87$, and RMSEA $=.074$. According to Manouchehri et al. (2015) the subscales with negative loads in most of the studies did not enjoy proper internal creditability. Perry (2014) argued that use of negatively worded items at times can cause confusion among participants. Monacis et al. (2013) recorded Cronbach's alpha value of .87 in the similar study conducted among 166 competitive level athletes from individual and team sports. Even as, Manouchehri et al. (2015) also reported the same alpha value in their study conducted among 373 young athletes from Pakdasht Township, Iran. 
The results on fitting wellness test also demonstrated acceptable and standard indicators values. The calculated values for the important indicators like Goodness of Fit Index (GFI), Comparative Fit Index (CFI) and Root Mean Square of Error (RMSEA) were reported within the standard region (Hair et al., 2010). MSOS-M revealed fit data of $\chi^{2}(d f=146)=321.76, \mathrm{CFI}=$ $.92, \mathrm{GFI}=.87, \mathrm{TLI}=.90, \mathrm{RMSEA}=.07, \mathrm{ChiSq} /$ $d f=2.20$. Our results are quite similar with the studies by Perry (2014) and Manouchehri et al. (2015).

Perry (2014) in his effort of presenting a new multidimensional measure of sportspersonship and evidence of its validity had recorded the data fit indicators as CFI = $.94, \mathrm{TLI}=.93$ and $\mathrm{RMSEA}=.04$ after several modification indices were performed. Whereas, Manouchehri et al. (2015) conducted a similar validation study among 373 young athletes from Pakdasht Township in order to determine the validity and reliability of MSOS questionnaire. They recorded valid data fit with GFI $=.90$, $\mathrm{TLI}=.91$ and $\mathrm{RMSEA}=.07$ representing fairly good values on used questionnaire internal stability.

There were a few limitations in this study. Firstly, the participants of this study came from the state of Sarawak. The participants were chosen from the state development programme for field hockey from 22 schools all over Sarawak. This could limit the generalizability of the study to Malaysian adolescents. Next, the maximum participant age for this study was 19 years old. Malaysian field hockey arena has recognised 19 years and below as the age limit for junior categories. International field hockey body considered 21 years old as junior range. So, this adolescent maximum age selected for this study could not be equally compared to some other similar studies internationally.

As this study established a reliable and psychometrically reliable Malay version questionnaire related to the expectancy-value theory and achievement goal theory, it might be influential for future studies to observe students' expectancy beliefs, subjective task values and sportsmanship attitude in numerous physical activities or sports practiced in Malay speaking countries.

\section{CONCLUSION}

Based on the construct analysis using Structural Equation Modeling (SEM) the current findings supported that EVMQ-M and MSOS-M possessed sufficient validity and internal reliability evidence to measure adolescence field hockey players in Malaysia.

Future studies could consider samples from different sports, different nationalities, and exercise related fields so that results can imply to wider sport communities beside it could possible yield some important and interesting results.

\section{ACKNOWLEDGEMENTS}

The authors would like to thank Centre for Sport and Exercise Sciences, University of Malaya and Sarawak State Sports Council (MSNS) for all the support, as well as the coaches and respondents who were involved in this study.

\section{REFERENCES}

Barkoukis, V., \& Mouratidou, K. (2015). Achievement goals and sportspersonship orientations in team sports. The moderating role of demographic characteristics. Ethics in Progress, 6(2), 74-92. doi:10.14746/ eip.2015.2.6.

Bentler, P. M. (1990). Comparative fit indexes in structural models. Psychological Bulletin, 107(2), 238-246. doi:10.1037/00332909.107.2.238.

Brislin, R.W. (1970). Back-translation for cross-cultural research. Journal of Cross Cultural Psychology, 1(3), 187-196. doi:10.1177/135910457000100301.

Chin, N. S., Khoo, S., \& Low, W. Y. (2009). Sex, age group and locality differences in adolescent athletes' beliefs, values and goal orientation in track and field. Journal of Exercise Science \& Fitness, $7(2), \quad 112-121 . \quad$ doi:10.1016/S1728869X(09)60014-9.

Conley, A. M. (2012). Patterns of motivation beliefs: Combining achievement goal and expectancy-value perspectives. Journal of Educational Psychology, 104(1), 32-47. doi:10.1037/a0026042. 
Duda, J. L., \& Nicholls, J. G. (1992). Dimensions of achievement motivation in schoolwork and sport. Journal of Educational Psychology, 84(3), 290-299. doi:10.1037/0022-0663.84.3.290.

Duda, J. L., Olson, L. K., \& Templin, T. J. (1991). The relationship of task and ego orientation to sportsmanship attitudes and the perceived legitimacy of injurious acts. American Alliance for Health, Physical Education, Recreation \& Dance, 62(1), 79-87. doi:10.1080/02701367.1991.1060 7522.

Eccles, J. S., Adler, T. F., Futterman, R., Goff, S. B., Kaczala, C. M., Meece, J. L., \& Midgley, C. (1983). Expectancies, values, and academic behaviors. In J. T. Spence (Eds.), Achievement and achievement motives: Psychological and sociological approaches (pp. 75-146). San Francisco, CA: W.H. Freeman.

Ghildiyal, R. (2015). Role of sports in the development of an individual and role of psychology in sports. Mens Sana Monographs, 13(1), 165-170. doi:10.4103/0973-1229.153335.

Hair, J. F., Black W.C., Babin, B. J., \& Anderson R.E. (2010). Multivariate data analysis: A global perspective $\left(7^{\text {th }}\right.$ ed.). Upper Saddle River, NJ: Pearson.

Manouchehri, J., Tojari, F., \& Hejabi, A. (2015). Determining validity and reliability of doping behavior measurement instrument in young athletes' society. Journal of Applied Environmental \& Biological Sciences, 5(7), 354-360. www.textroad. com.

Monacis, L., Estrada, O., Siantra, M., Tanucci, G., \& Palo. V. D. (2013). Self-determined motivation, sportmanship, and sport orientation: A mediational analysis. Procedia - Social \& Behavioral Sciences, 89(2013), 461-467. doi:10.1016/j. sbspro.2013.08.878.
Nicholls, J. G. (1989). The competitive ethos and democratic education. Cambridge, MA: Harvard University Press.

Nunnally, J. C. (1978). Psychometric theory (2 $2^{\text {nd }}$ ed.). New York, NY: McGraw-Hill.

Østerlie, O., Løhre, A., \& Haugan, G. (2018). The Expectancy-value questionnaire in physical education: A validation study among Norwegian adolescents. Scandinavian Journal of Educational Research, 63(6), 869-883. doi:10.1080/00 313831.2018 .1453867 .

Perry, J. L. (2014). Redefining sportspersonship: A compliant and principled model. (Unpublished doctoral dissertation, University of Hull, United Kingdom).

Plante, I., O’Keefe, P. A. \& Théorêt, M. (2013). The relation between achievement goal and expectancy-value theories in predicting achievement-related outcomes: A test of four theoretical conceptions. Motivation \& Emotion, 37(1), 65-78. doi:10.1007/s11031-012-9282-9.

Roure, C., \& Lentillon-Kaestner, V. (2018). Development, validity, and reliability of a French expectancy-value questionnaire in physical education (FEVQ-PE). Canadian Journal of Behavioural Science, 50(3), 127-135. doi:10.1037/cbs0000099.

Saeed, J., Abd Rahim, M. S., \& Abida, N., (2015). Relationship between motivational intensity and player's performance of Pakistani national sport. European Journal of Sports \& Exercise Science, 4(4), 1-6. http://www.scholarsresearchlibrary.com.

Sharma, S. (1996). In applied multivariate techniques. New York, NY: John Wiley and Sons.

Teo, E. W., Lee, Y. Y., Khoo, S., \& Morris, T. (2015). Translation and validation of the Malay version of Shiffman-Jarvik withdrawal scale and cessation selfefficacy questionnaire: A review of psychometric properties. Health \& Quality 
of Life Outcomes, 13(1), 1-9. doi:10.1186/ s12955-015-0238-0.

Vallerand, R. J., Brière, N. M., Blanchard, C. M., \& Provencher, P. (1997). Development and validation of the multidimensional sportspersonship orientations scale. Journal of Sport \& Exercise Psychology, 19(2), 197-206. doi:10.1123/ jsep.19.2.197.

Wigfield, A., \& Cambria, J. (2010). Expectancyvalue theory: Retrospective and prospective. In T. Urdan \& S. Karabenick (Eds.). The decade ahead: Theoretical perspectives on motivation and achievement (Advances in Motivation and
Achievement, Vol. 16 Part A). Bingley, England: Emerald Group Publishing Limited, pp. 35-70. doi:10.1108/S07497423(2010)000016A005

Worthington, R. L., \& Whittaker, T. A. (2006). Scale development research: A content analysis and recommendations for best practices. The Counseling Psychologist, 34(6), 806-838. doi: $10.1177 / 0011000006288127$.

Zhu, X., Sun, H., Chen, A., \& Ennis, C. D. (2012). Measurement invariance of expectancyvalue questionnaire in physical education. Measurement in Physical Education \& Exercise Science, 16(1), 41-54. doi:10.10 80/1091367X.2012.639629. 